\title{
BIM Teaching Strategy for Surveying Students in China
}

\author{
Liu Yan \\ School of Construction Management and Real Estate \\ Chongqing University \\ Chongqing, China \\ ly1235813@sina.com
}

\begin{abstract}
Building Information Modeling (BIM) has won rapid acceptance in the AEC industry around the world, especially in China over recent years. The popularity of BIM will involve more new talents in the surveying industry and will simultaneously make demands on the surveying teaching in universities and colleges. This paper presents an overview on experiences and lessons learned during the introduction of BIM in construction management education and training. It illustratively shows that the introduction of BIM allows educators to design new teaching methods that use more realistic cases, supporting students with learning how to apply different formal project management methods to real-world project management problems. Some suggestions will be put forward to improve the current surveying education.
\end{abstract}

Keywords- Building Information Modeling; Quantity surveying; Case Study; Education; Surveying Teaching.

\section{INTRODUCTION: WHY IT'S BIM IN SURVEYING TEACHING IN CHINA}

\section{A. The proliferation of BIM}

Nowadays, there is an irreversible trend of changing gradually from traditional 2D representation of building product to 3D product model and streamlined lifecycle management. Building Information Modeling (BIM) brings brand-new inspiration for the whole building industry, and it is an information-based technical revolution. Around the world there is publicity about the influence of BIM. The press and governments are proclaiming that BIM will be transformational in the approach to procuring, designing, and constructing projects.

In China, compared to the Beijing Olympic Games where only the "Water Cube" stood out as an implementation of BIM to some degree, the Expo Cultural Center, the German Expo Pavilion and other venues in the Shanghai Expo have brought greater reputation to BIM. The Shanghai Tower, a super-tall skyscraper under construction in the Pudong district of Shanghai, which will be the tallest building in China and the second-tallest in the world at the time of its completion, have been boosted by the news that its whole life cycle management will fully utilize BIM. The application of BIM pushed BIM in China into a new height.

The 2011-2015 National Program of AEC Informatization Development was published in May 2011 by China Ministry of Housing and Urban-Rural Development, and set out its intention to decide BIM as one of the core technologies in survey, design and building industry in the

\author{
Li Shirong \\ School of Construction Management and Real Estate \\ Chongqing University \\ Chongqing, China \\ ly1235813@sina.com
}

12th five-year national plan in China. ${ }^{[1]}$ At the same time, an order was given for creating five BIM standards by the Ministry. Once issued, these standards will accelerate the development and popularization of BIM application speed. Therefore, it is obvious that the demand for all kinds of applied talents will be more urgent in the next 10 years or longer.

BIM has been advocated as a game changer for the construction sector. It is promising much, but does the industry have the appetite to change?

\section{B. When quantity surveying meets BIM}

Cost is always the major consideration obsessing both the AEC industry and its clients. As a visual database of building components, BIM can provide accurate and automated quantification, and assist in significantly reducing variability in cost estimates. BIM tools have addressed the significant limitations of 2D drawings that lack the rich 3D context which estimators need in order to identify important cost-sensitive design features. ${ }^{[2]}$

\section{THE EDUCATION OF SURVEYORS ON THE HORNS OF A DILEMMA}

\section{A. Great demand for quantity surveyors}

China has successfully maintained its economic development pace through intense public investment in infrastructure and building projects. This situation puts forward new challenges and an increasingly urgent demand for quantity surveyors to improve their comprehensive qualities.

Many firms are looking to increase their capacity to win and deliver big BIM projects. One of the challenges they face is how to find qualified staff to lead these projects, because services traditional quantity surveyors provided are far below to meet the BIM market demands.

\section{B. Current situation needs to change}

The education and training of quantity surveyors is often subjected to a directional pull from universities. Academic institutions seek to address competencies whilst instilling further academic skills. Quantity surveying is a multidisciplinary applied major and requires strong ability to doit-by-yourself and logical thinking. Its training should be different from other major's.

As BIM introduces the innovative design concept, advanced lean project construction and management, AEC 
industry needs more and more high-quality skilled talents mastering technology, economy and management and having a strong practical ability. We must have the courage to bring forth new ideas in professional teaching practice and explore new ways of cultivating talents.

The general solution is to strengthen the experiment teaching through the organization of a large number of experimental teaching, curriculum design, and field work. Most universities have common in this idea, but overall effect is not ideal due to the limitation of the past traditional method which can only meet basic teaching requirement.

\section{BIM talents need education}

According to RICS 2011 Building Information Modeling Survey Report, there is a question: Would your organization be interested in BIM training? Survey results are as follows:

TABLE I. RICS 2011 BIM SURVEY REPORT RESULTS

\begin{tabular}{|l|c|c|}
\hline $\begin{array}{l}\text { Possible RICS } \\
\text { actions }\end{array}$ & All respondents(291) & $\begin{array}{l}\text { All with } \\
\text { project } \\
\text { experience(65) }\end{array}$ \\
\hline $\begin{array}{l}\text { Provide guidance on } \\
\text { BIM }\end{array}$ \\
\hline Provide training & 67 & \multicolumn{1}{|c|}{85} \\
\hline $\begin{array}{l}\text { Support data exchange } \\
\text { standards development }\end{array}$ & 46 & 58 \\
\hline $\begin{array}{l}\text { Influence BIM } \\
\text { input/output } \\
\text { requirements }\end{array}$ & 37 & 52 \\
\hline $\begin{array}{l}\text { Define levels of BIM } \\
\text { working for reference } \\
\text { in professional serices } \\
\text { agreements }\end{array}$ & 36 & 49 \\
\hline $\begin{array}{l}\text { Influence/lead on new } \\
\text { forms of contract }\end{array}$ & 34 & \\
\hline
\end{tabular}

Irrespective of professional group, at least $46 \%$ and generally more than $50 \%$ of respondents said their firms would be interested in BIM training. In most cases, respondents from firms that were involved in BIM projects within the last 12 months were substantially more interested in BIM training. All respondents support for possible RICS BIM actions

More respondents believe BIM guidance and training can immediately bring benefits while other actions such as Support data exchange standards development, Influence BIM input/output requirements, and Define levels of BIM working for reference in professional services agreements, Influence/lead on new forms of contract would be confronted with uncertainty currently.

Not unique but as a double, there is a similar question in China AEC Industry BIM Application Research Report 2011(part 4: the application plan or expectations BIM): Is it possible that in 2011 your company will use BIM software? If not, what's the main reason, lack of BIM talents, high cost lack of urgency or other reason? It can be found in the investigation results that the main reason that they aren't likely to use BIM is "lack of BIM talents". The proportion of this reason exceeds the sum of all other reasons. ${ }^{[4]}$
Is it possible that in 2011 your company will use BIM software

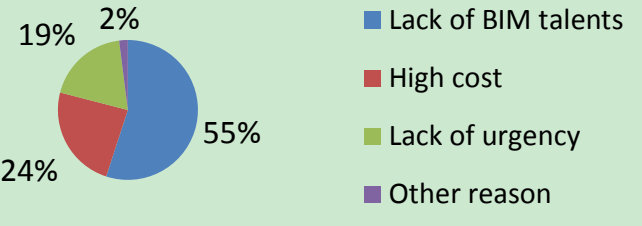

Figure 1: China AEC Industry BIM Application Research Report 2011 results

\section{How TO Adopt BIM In SURVEYING TEACHING}

\section{A. The current situation of surveying teaching}

Quantity surveying is a comprehensive and practical major in connection with Construction Management and Civil Engineering. Because of the interdisciplinary and the practicality, how to build a practice teaching system, which not only establishes the theoretical foundation but also is relatively independent, becomes the key to achieve the goal of cultivating talents. To accomplish this, we need to strengthen training of teachers, to constantly update the knowledge of teachers, to explore new teaching modes and teaching methods so as to adapt to the requirements of the development of this applied profession. It has theoretical significance and practical value to change the situation where practice teaching is neglected and to raise a thorough practical teaching system based on BIM as the platform.

\section{B. The ideal adoption of BIM in surveying teaching}

The quantity surveying teaching and training platform based on the BIM should realize two kinds of requirements stated as below:

1)Teaching requirement: The quantity surveying is an applied subject. In the professional teaching stage, we should not merely offer the form of classroom teaching in the traditional way. This kind of teaching mode divides the professional knowledge into large amounts of knowledge points. For students without any practical experience and engineering concept, it is really hard to establish a professional knowledge system, not to speak of obtaining manipulative ability. The ideal professional teaching should have a large number of real cases study as the main theme, so that the knowledge can be consolidated and then be applied in the solid foundation. Using BIM, it can be achieved in the change of thinking from $2 \mathrm{D}$ to $3 \mathrm{D}$. Teachers can start with professional basic course and then combine organically with professional content by showing the building, structure, environment in the form of 3D model. In this way students would have an immersed sense thus stimulating the learning interest.

2) Employment market requirements: With the development of society, the complexity of the project has been strengthened. The project scale has been increased. Alien structure projects appear constantly. Owners have more and more high requirements for energy saving, low 
carbon and sustainable building and maintenance. The cost control has become stricter and stricter. A college student will find classroom knowledge out of date once stepping out of the school gate or it is greatly different between practical work and school learning to a great extent. This radical change put forward very serious challenges for quantity surveying students. It is necessary to obtain practical skills for quantity surveying students through the professional platform.

\section{Possible limiting conditions}

- Universities and colleges need to provide strong support, including purchasing enough software and hardware, arranging laboratories, which cost huge investment. The scale of teaching will be limited by laboratories, facilities, and the resources of the teaching staff.

- The social effect will be higher than economic benefit. The improvement of students' ability and the teaching quality is indirect and it takes long time to see the return of investment.

- The traditional courses refer to the teacher's knowledge level. The teacher will teach what they know well. The teacher and students will find it difficult to get used to the new teaching content, structure and methods. The careless introduction of BIM could be detrimental to design thinking and its central role in architectural education. ${ }^{[5]}$

- According to the domestic university system, there are eight or nine construction-related majors, but these majors are scattered in secondary-level institutes (for example School of Architecture and Urban Planning, School of Civil Engineering, School of Urban Construction and Environmental Engineering, School of Construction Management and Real Estate etc. in Chongqing University). The biggest advantage of BIM Implementation lies in synergism and sharing. This kind of specialty setting is not conducive to promoting the BIM in universities in accordance with practice; it is easy to accept Revit in School of Architecture and Urban Planning, while it is tough to popularize Revit in other schools.

In conclusion, universities and colleges haven't got enough pressure to keep BIM adoption in surveying teaching going.

\section{THREe CASES IN CHINA}

\section{A. Master of Engineering}

The Huazhong University of Science and Technology (HUST) is a national key university directly under the administration of the Ministry of Education of China. School of Civil Engineering \&Mechanics takes the lead in Master of Engineering in BIM scope in China. The degree is typically awarded to students who complete undergraduate courses lasting four years when taken full-time. BIM experts in universities and industry will be employed to compile BIM textbook series and conduct BIM courses.
There are six courses on BIM in its curriculum provision: 1) "Project Management Informatization and BIM": teaching the project management informatization, the position and role of BIM in the project management informatization.

2) "The BIM principle ": teaching what is BIM and the basic working principle of BIM.

3) "The BIM tools and method": teaching all kinds of tools and methods supporting realizing BIM value.

4) "The BIM application cases ": teaching all types of BIM application cases for reference.

5) "The BIM project organization ": teaching organization form and method of BIM project.

6) "The special BIM application technology ": teaching several BIM special application technologies besides routine use.

It is an important way to learn BIM specialized knowledge and improve BIM project management implementation for on-the-job technical and project management personnel. This action will train senior BIM talents for the domestic construction industry, easing the situation where at present there are only BIM software operating personnel, while comprehensive BIM management talented staffs are lacking. ${ }^{[6]}$

\section{B. BIM competition Identify}

Tsinghua Sware Software Hi-Tech Co. Ltd (THSWARE) is the leading construction industry software and solutions services provider in China. Thsware is specialized in providing AEC information solutions including BIM services.

The national Thsware Cup BIM contest has won great reputation. According to the collaborative working idea, it advocates team work among students from majors of architecture, civil engineering, equipment engineering, project management and other relevant professionals in the industrial chain. They will act as three separate important roles (designer, quantity surveyor and constructor). The competition involves engineering design (including construction scheme, construction rules, architecture drawing, structure drawing, MEP drawing), quantity surveying (including civil engineering quantities, MEP quantities and the engineering valuation), project management (planning of project construction, project planning, construction layout) and virtual reality (design scheme displays, construction process simulation), etc. Throughout the competition, team members must work with each other and make decisions one after another. Competitors show their works in the preliminary rounds of the competition and match skills against each other in the final with the help of BIM software series. Experience has shown that it is a challenging and interesting competition which promotes the construction of practical teaching and facilitates the mastery of BIM software modeling technology.

Academic competitions encourage growth and support of students' education and interest in the industry. Students gain experience, recognition, scholarships and more. 


\section{Classroom courses}

Chongqing University is a nationally famed comprehensive key university in China. The specialty in Quantity Surveying of Chongqing University is famous for its high quality education and its annually high undergraduate employment rate. Chongqing University holds a course called BIM panorama.

TABLE II. THE COURSE ARRANGEMENT OF BIM PANORAMA IN CHONGQING UNIVERSITY

\begin{tabular}{|c|c|c|}
\hline Lecture & Date & Topic \\
\hline 1 & Feb 23 & Class description/ BIM Introduction (1) \\
\hline 2 & Mar 1 & BIM Introduction(2) \\
\hline 3 & Mar 8 & BIM application in Surveying \\
\hline 4 & Mar 15 & BIM application in Scheduling \\
\hline 5 & Mar 22 & BIM and design management \\
\hline 6 & Mar 29 & Interim report (1) \\
\hline 7 & Apr 5 & Interim report (2) \\
\hline 8 & Apr 12 & BIM and energy consumption analysis \\
\hline 9 & Apr 19 & BIM and urban planning \\
\hline 10 & Apr 26 & difficulties and challenges of BIM \\
\hline
\end{tabular}

Its Interim report is a PPT presentation analyzing cases home and abroad. The PPT should explicate:

1) Project introduction and why this project used BIM;

2) What problems can be solved with the assistance of BIM application?

3) How to apply BIM in this project and in which stage?

4) How does BIM help project succeed?

5) What difficulties and challenges appeared in the application of BIM? The final paper is an opportunity to synthesize the learning of the course. Students must write on the topic "BIM and ***” (*** refer to what has something to do with BIM they are interested in). The paper must include:

1) Introduction (why you want to write this theme)

2) Status description

3) Why BIM is needed (what problems BIM can solve)?

4) The conclusion and suggestion

5) References

\section{Suggestions AND CONCLUSION THREE}

In light of the circumstances of quantity surveying teaching in China, there are six ways to adopt BIM in surveying teaching:

1) Offer short-term training for companies

2) Offer training and professional qualification for teachers

3) Build laboratories through the joint efforts

4) Take up research projects

5) Compile textbooks
6) Carry out communication in the form of lectures and so on

There are many matured quantity takeoff BIM software at home and abroad stated as below:

TABLE III. MATURED QUANTITY TAKEOFF BIM PRODUCTS

\begin{tabular}{|c|c|}
\hline In China & International \\
\hline Lubansoft Estimator & Autodesk QTO \\
\hline $\begin{array}{c}\text { Glodon QTO for Architecture and } \\
\text { Structure software }\end{array}$ & Innovaya Visual Applications \\
\hline Thsware-3D Account & RIB iTWO \\
\hline & $\begin{array}{c}\text { Vico Software Vico Takeoff } \\
\text { Manager }\end{array}$ \\
\hline
\end{tabular}

Through selection among software in Chongqing University, the most suitable quantity surveying BIM software for teaching BIM is Thsware BIM software series.

If we pay attention to BIM innovation and technology application in the university education and launch simulation teaching based on BIM, we believe that the surveying teaching can be improved effectively, which will provide plenty of compound talents with technology and management for the development of construction industry.

This paper investigates the adoption of BIM in surveying teaching in China currently and explores the future methods for young surveyors and universities. Students, schools and companies can achieve mutual benefits and win-win results through BIM application - from 3D visualization to construction-caliber quantity takeoff and even lean scheduling with flow line theory and evolutionary cost planning.

\section{ACKNOWLEDGMENT}

The author would like to thank and acknowledge Research Center for International Construction Economics \& Management for generous and expert support to this study.

\section{REFERENCES}

[1] http://www.mohurd.gov.cn/zcfg/jswj/gczl/201105/t20110517_203420 .htm, 2011

[2] Sabol, Louise. "Challenges in Cost Estimating with Building Information Modeling. "News: Design + Construction Strategies. Web. 15 Sept. 2009.<http://www.dcstrategies.net/news.php>.

[3] RICS 2011 Building Information Modeling Survey Report

[4] China AEC Industry BIM Application Research Report 2011

[5] Cheng R. Suggestions for an integrative education. Report on Integrated Practice. Washington DC : The American Institute of Architects. Section 5, pp 1-10,2006

[6] http://blog.sina.com.cn/s/blog_620be62e0100x4ku.html 